\title{
Knowledge and attitudes of entry-level and final-level physical therapy students about evidence-based practice - A cross-sectional study
}

\author{
Felipe Reis', Julia Rodrigues Siqueira², Gabriela Andrade ${ }^{3}$, Leandro Calazans Nogueira ${ }^{4}$, \\ Ney Meziat-Filho ${ }^{5}$, Luís Cláudio Lemos Correia ${ }^{6}$
}

'Corresponding author. Federal Institute of Rio de Janeiro. Rio de Janeiro, Rio de Janeiro, Brazil.ORCID: 0000-0002-9471-1 174. felipe.reis@ifri.edu.br ${ }^{2}$ Federal Institute of Rio de Janeiro. Rio de Janeiro, Rio de Janeiro, Brazil. ORCID: 0000-0001-8992-4063. julia.r.siqueira@hotmail.com ${ }^{3}$ Federal Institute of Rio de Janeiro. Rio de Janeiro, Rio de Janeiro, Brazil. ORCID: 0000-0003-2529-8731. andradegabriela@outlook.com.br ${ }^{4}$ University Center Augusto Motta, Federal Institute of Rio de Janeiro. Rio de Janeiro, Rio de Janeiro, Brazil. ORCID: 0000-0002-0177-9816. leandro.nogueira@ifri.edu.br ${ }^{5}$ University Center Augusto Motta. Rio de Janeiro, Rio de Janeiro, Brazil. ORCID: 0000-0003-2794-7299. neymeziat@gmail.com ${ }^{6}$ BAHIANA - School of Medicine and Public Health. São Rafael Hospital. Salvador, Bahia, Brazil. ORCID: 0000-0002-6910-1366. luis.correia@bahiana.edu.br

\begin{abstract}
I Evidence-based practice (EBP) has gained widespread acceptance in the health profession. Little is known about the attitudes, knowledge, and behavior about EBP of physical therapy students at different levels in Brazil. OBJECTIVES: To compare the EBP-related knowledge, practice, attitudes between the entry-level and final-level physical therapy students. METHODS: A cross-sectional study including 60 physical therapy students was conducted. The participants completed a questionnaire to determine their attitudes, knowledge, practice skills and barriers regarding EBP. The survey consisted of 38 items about EBP (relevance, terminology and practice skills) and 7 items related as barriers to adopt the EBP during physical therapy graduation. Total scores were calculated. For each of the three sections scores of a 5-point Likert scale were considered. RESULTS: The sample was composed of 40 students in the entry-level and 20 in the final-level. The mean age of the sample was 23.3 $(S D=7.6)$. The mean score of the sample in the EBP survey was $83.5(S D=20.8)$. We did not find difference between finallevel group (mean=101.6; $S D=17.8$ ) and entry-level students (mean=74.5; SD= 15.8) $(p=.45)$. Students of the final-level group presented higher scores in all EBP sections (relevance, terminology, practice skills). A higher mean difference was observed in terminology $(-17.8)$ section. The most common barriers reported by the students of both groups were "lack of knowledge of statistics" (19.3\%), "lack of time" (17.7\%) and "language" (16\%). CONCLUSION: The difference in all sections about evidence based knowledge and attitudes where not expressive between the final-level and the entrylevel students. Regarding practice skills, students were not confident about their abilities in the EBP steps.
\end{abstract}

KEYWORDS: Evidence-Based Practice. Physical Therapy Specialty. Education. 


\section{Introduction}

Health care practitioners are increasingly urged to ensure that they are delivering care based on the best current research evidence, which is the use of the evidence-based practice (EBP) to make clinical decisions ${ }^{1-3}$. Since the term EBP was first coined in the mid-1990s ${ }^{4}$, the integration of EBP in health professional education has continued to grow. Although EBP has initiated in medicine, it has been established for all health professions such as physical therapy, occupational therapy, nursing and psychology ${ }^{5-8}$.

Evidence-based practice is a five-step model: (i) formulating the clinical question, (ii) searching the evidence, (iii) appraising the evidence, (iv) incorporating evidence into decision making, and ( $v$ ) evaluating the process ${ }^{4,9,10}$. In this process, clinicians should integrate best research evidence with clinical expertise and patient preferences, producing the most appropriate and effective service ${ }^{4,11}$. The proficiency of physiotherapists' clinical practice may enhance with the engagement of both research and clinical findings ${ }^{11}$ and help prevent the misuse, overuse, and underuse of healthcare services ${ }^{12}$. In an era of growing accountability of healthcare practitioners, EBP steps may provide a useful framework within which to work. Indeed, this has led some professionals to argue that there is a moral obligation to base decision-making on research findings ${ }^{13}$.

There is a growing body of literature relating to the short-term effectiveness of training in improving knowledge and raising awareness of EBP principles for clinical physiotherapists ${ }^{14-16}$. However, there is limited evidence that the EBP behavior of clinicians can be maintained in the long term following EBP education programs ${ }^{17}$ multi-component implementation intervention, \naddressing earlier identified determinants, was carried out in three $\backslash$ nareas comprising 28 physical therapy practices including 277 physical $\backslash$ ntherapists (PTs. Mclnerney and Suleman ${ }^{18}$ emphasize that unless students are introduced to EBP during the graduation process, the concept of "best practice" may be difficult to achieve. Thus, it is relevant that physical therapy students still struggle to see the relevance of theory and evidence in their activity ${ }^{19}$.
To date, little is known about EBP among undergraduate physical therapy students in Brazil. Therefore, this study aimed to compare the EBPrelated knowledge, practice, and attitudes between the entry-level and final-level physical therapy students. Our primary hypothesis is that students from the final-level group present higher levels of understanding of EBP relevance, knowledge, and practice skills when compared to students from the entry-level students.

\section{Methods}

\section{Ethical Issues}

The study received ethical approval from the Ethics Board Committee of the Instituto Federal do Rio de Janeiro (CAAE 83321917.7.0000.5268). All participants signed the Informed Consent Form prior to the study. Participants initially completed demographic questions relating to age, gender, and the current year in physical therapy course at the time of the evaluation. An EBP survey was applied to investigate the relevance, knowledge, practice skills and barriers. None of the participants had any contact with EBP concepts during graduation. The study was carried out from July 2016 to January 2017.

\section{Setting and participants}

A cross-sectional study was adopted to investigate the difference between entry-level (first year) and final-level (last year) students about the relevance, terminology, practice, and barriers of EBP. The study protocol follows the recommendation of the The Strengthening the Reporting of Observational Studies in Epidemiology (STROBE) Statement ${ }^{20}$. A convenient sample of students from the entry-level and the final-level of physical therapy course at Instituto Federal do Rio de Janeiro were invited to participate in this study. We included students if 1) they were actively registered in the first or last year of physical therapy course graduation, and 2) aged over 18 years. Participants were excluded if they attended to any EBP course; those who did not answer all questions regarding demographic information or EBP questionnaire; who are attending in the first or 
the last year courses but were not enrolled in their respective years (i.e., cases of pending or advanced subjects' of the curriculum).

\section{Procedure}

A survey instrument was developed for this study based on questions present in the original version of the Evidence-Based Practice Profile Questionnaire (EBP2Q). The survey consisted of 45 items where the first 38 items create a profile of three self-reported sections relating to EBP (relevance, terminology and practice skills). In the last section, participants should select as many as they want from a list of 7 items which include factors they consider as barriers to adopt the EBP during graduation. Scores were calculated for each of the three sections, on a 5-point Likert scale (Table 1). The students received the questionnaire in hand and filled it out at the moment without the help of the examiner. The score of the instrument was calculated by adding the response values of each question (minimum 1 and maximum 5), totaling 165 points with higher scores indicating better knowledge of the EBP domains. For each question about EBP domains, we considered 1.0 as an important mean difference. This difference was chosen because 1.0 point represents a change in the classification of the Likert scale. The structure of the survey is presented in Table 1.

Table 1. Structure of the survey with the separate sections and contained statements

\begin{tabular}{|c|c|c|}
\hline Section & Item numbers & Description \\
\hline I. Relevance ${ }^{a}$ & $1-5$ (5 items) & $\begin{array}{l}\text { Attitude towards expanding own competence in the } \\
\text { Evidence-Based Practice, expressed on a scale from } 1 \\
\text { to } 5(1-\text { not at all true; } 5 \text { - very true) - Total: } 25 \\
\text { points }\end{array}$ \\
\hline II. Terminology $y^{a}$ & 6-22 (17 items) & $\begin{array}{l}\text { The level of knowledge about the terminology related } \\
\text { to scientific research; given terms and issues were } \\
\text { rated on a scale from } 1 \text { to } 5 \text { ( } 1 \text { - never heard the } \\
\text { term; } 5 \text { - understand and could explain to others) - } \\
\text { Total: } 85 \text { points }\end{array}$ \\
\hline III. Practice Skillsa & $23-33$ ( 11 items) & $\begin{array}{l}\text { Confidence in skills related to Evidence-Based Practice } \\
\text { rated on a scale from } 1 \text { to } 5(1-\text { not at all confident; } \\
5 \text { - very confident) - Total: } 55 \text { points }\end{array}$ \\
\hline IV. Barriers & 33- 40 (7 items) & $\begin{array}{l}\text { Lack of time; Lack of knowledge about statistics; lack } \\
\text { of stimulus; Lack of knowledge about database; Lack } \\
\text { of accesses to papers; Language; Lack of knowledge } \\
\text { of methodology. }\end{array}$ \\
\hline
\end{tabular}

a. all items based on a five-point Likert scale

\section{Statistical Analysis}

Data were analyzed using the SPSS version 22 (SPSS Inc, Chicago, IL) for Microsoft Windows. Response frequencies for the survey questions were determined and displayed in tabular and graphic formats. For demographic data and those items with a 5-point Likert scale, descriptive analysis (mean, standard deviation) was calculated. Section scores according to Likert values were used to calculate the mean difference between groups using independent t-test. A $p \leq 0.05$ was considered statistically significant. The primary hypothesis of this study is that finallevel students will present higher total scores when compared to entry-level students. Therefore, we considered the total score as a primary outcome and sections and questions scores as secondary outcomes. The Shapiro-Wilk test was used to determine if the variables present normal distribution.

\section{Results}

The sample was composed of $50(83.3 \%)$ women and $10(16.7 \%)$ men. The mean age was 23.3 years $(S D=7.6$; range $=18$ to 56$)$. The first-year students group represented $66.7 \%(n=40)$ of the sample, and 
the mean age was 22.3 years $(S D=7.8$; range $=18$ to 56); and the final-level students group represented $27.3 \%(n=20)$ of the sample, and the mean age was 25.3 years ( $S D=7.0$; range $=21$ to 53 ). Our sample represents $66.7 \%$ of the students in the first year. We assessed $42(70 \%)$ final-level students. However, 22 were excluded due to have been trained in a 30 hour evidence based practice course.

The mean score of the sample in the EBP survey was $83.5(S D=20.8$; range $=45$ to 131$)$. The total score of the survey between students of the final-level group (mean=101.6; $S D=17.8$ ) and the entry-level students (mean $=74.5 ; \mathrm{SD}=15.8$ ) was not statistically significant $(p=.45)$. Regarding EBP sections, students of the final-level group presented higher scores in all sections. Higher mean difference was observed in terminology followed by practice skills domain. However, only the relevance domain was statistically significant (Table 2).

Table 2. Comparison between entry-level and final-level group of students related to EBP section scores

\begin{tabular}{lcccc}
\hline Section & $\begin{array}{r}\text { Entry-level group } \\
\text { Mean }( \pm \text { SD) }\end{array}$ & $\begin{array}{c}\text { Final-level group } \\
\text { Mean }( \pm \text { SD) }\end{array}$ & Mean Difference & $p$ \\
\hline Relevance & $17.7(2.6)$ & $20.3(1.6)$ & -2.5 & .01 \\
Terminology & $27.8(9.5)$ & $45.7(12.6)$ & -17.8 & 0.1 \\
Practice Skills & $28.8(8.8)$ & $35.6(7.4)$ & -6.7 & 0.3 \\
\hline
\end{tabular}

In relevance section, the final-level students presented a significant difference in mean in one question "I am aware of EBP in my profession" (MD = -1.0; $\mathrm{p}<.05$ ) (Table 3). In terminology section, final-level group showed to be more familiar with six concepts. However, only two concepts showed significant mean difference "Number needed to treat" (MD = -1.1; $p<.05$ ) and "Publication bias" (MD $=-1.2 ; p<.05)$ (Table 4). Practice skills section reached higher mean difference especially in regard to questions "Formulated a clearly answerable question that defines the client or problem, the intervention and outcome $(s)$ of interest" (MD = -2.2; $p<.05$ ); "Integrated research evidence with your expertise" $(M D=-2.3 ; p<.05)$ and "Considered your clients' preferences when making clinical/professional decisions" (MD $=-2.4 ; p<.001$ ) (Table 5).

Table 3. Results of the Relevance section of the EBP survey considering the students' level.

\begin{tabular}{|c|c|c|c|}
\hline Relevance section & $\begin{array}{l}\text { Entry-level Group } \\
\text { Mean (SD) }\end{array}$ & $\begin{array}{l}\text { Final-Level Group } \\
\text { Mean (SD) }\end{array}$ & $\begin{array}{c}\text { Mean } \\
\text { Difference }\end{array}$ \\
\hline $\begin{array}{l}\text { 1. I understand what is meant by } \\
\text { the term evidence-based } \\
\text { practice (EBP) }\end{array}$ & $3.25(1.0)$ & $4.10(.64)$ & $-.850 *$ \\
\hline $\begin{array}{l}\text { 2. I am aware of EBP in my } \\
\text { profession }\end{array}$ & $3.57(1.0)$ & $4.60(.50)$ & $-1.02 *$ \\
\hline $\begin{array}{l}\text { 3. Application of EBP is necessary } \\
\text { in my work }\end{array}$ & $3.95(.67)$ & $4.55(.60)$ & -.60 \\
\hline $\begin{array}{l}\text { 4. EBP helps me make decisions } \\
\text { about clients in my work }\end{array}$ & $3.75(.77)$ & $4.35(.48)$ & $-.60 *$ \\
\hline $\begin{array}{l}\text { 5. Workplace experience is the } \\
\text { most reliable way to know what } \\
\text { really works }\end{array}$ & $3.25(.87)$ & $2,75(.91)$ & .50 \\
\hline
\end{tabular}




\begin{tabular}{lccc}
\hline Terminology section & $\begin{array}{c}\text { Entry-level Group } \\
\text { Mean (SD) }\end{array}$ & $\begin{array}{c}\text { Final-level Group } \\
\text { Mean (SD) }\end{array}$ & $\begin{array}{c}\text { Mean } \\
\text { Difference }\end{array}$ \\
\hline 6. Relative risk & $1.85(1.0)$ & $2.80(1.10)$ & -.95 \\
7. Absolute risk & $1.90(1.0)$ & $3.05(1.27)$ & -1.15 \\
6. Systematic review & $1.73(1,0)$ & $3.50(1.05)$ & -1.77 \\
9. Odds ratio & $1.25(.74)$ & $1.60(.82)$ & $-.35^{*}$ \\
10. Meta analysis & $1.30(.72)$ & $3.05(1.05)$ & -1.75 \\
11. Number needed to treat & $1.30(.68)$ & $2.40(1.14)$ & $-1.10^{*}$ \\
12. Confidence interval & $1.33(.89)$ & $2.75(1.07)$ & -1.42 \\
13. Publication bias & $1.33(.65)$ & $2.60(1.18)$ & $-1.27^{*}$ \\
14. Forest plot & $1.10(.30)$ & $1.40(.75)$ & $-.30^{*}$ \\
15. Intention to treat & $1.95(1.01)$ & $2.60(1.39)$ & $-.65^{*}$ \\
16. Statistical significance & $2.15(1.14)$ & $3.15(1.04)$ & -1.0 \\
17. Minimum clinically worthwhile effect & $1.88(.96)$ & $3.10(1.21)$ & -1.22 \\
18. Clinical importance & $2.33(1.04)$ & $3.35(1.08)$ & -1.02 \\
19. Randomised controlled trial (RCT) & $1.68(1.02)$ & $3.40(1.09)$ & -1.72 \\
20. Dichotomous outcomes & $1.55(.98)$ & $2.05(1.35)$ & -.50 \\
21. Continuous outcomes & $1.53(.93)$ & $2.40(1.31)$ & $-.87^{*}$ \\
22. Treatment effect size & $1.75(1.0)$ & $2.50(1.14)$ & -.75 \\
\hline F & & &
\end{tabular}

Table 5. Results of the Practice skills section of the EBP survey considering the students' level

\begin{tabular}{lccc}
\hline Practice skills section & $\begin{array}{c}\text { Entry-level Group } \\
\text { Mean (SD) }\end{array}$ & $\begin{array}{c}\text { Final-level Group } \\
\text { Mean (SD) }\end{array}$ & $\begin{array}{c}\text { Mean } \\
\text { Difference }\end{array}$ \\
\hline $\begin{array}{l}\text { 23. Research Skills } \\
\text { 24. Computer skills }\end{array}$ & $2.90(1.08)$ & $3.10(1.0)$ & -.20 \\
$\begin{array}{l}\text { 25. Ability to identify gaps in your } \\
\text { knowledge }\end{array}$ & $3.20(1.15)$ & $3.80(.95)$ & -.60 \\
$\begin{array}{l}\text { 26. Ability to convert your information needs } \\
\text { into clearly answerable questions }\end{array}$ & $2.80(.96)$ & $3.45(.94)$ & -.65 \\
$\begin{array}{l}\text { 27. Awareness of major information types } \\
\text { and sources }\end{array}$ & $2.57(.93)$ & $3.30(.73)$ & -.72 \\
$\begin{array}{l}\text { 28. Ability to search an electronic database } \\
\text { 29. Ability to access evidence (get copies of } \\
\text { articles or reports) }\end{array}$ & $2.78(.94)$ & $3.30(.73)$ & -.52 \\
$\begin{array}{l}\text { 30. Ability to critically analyse evidence } \\
\text { against set standards ie quality scoring }\end{array}$ & $2.65(1.12)$ & $3.15(.81)$ & $-.45^{*}$ \\
$\begin{array}{l}\text { 31. Ability to determine how valid (close to } \\
\text { the truth) the material is }\end{array}$ & $2.18(.84)$ & $3.25(.96)$ & -.60 \\
$\begin{array}{l}\text { 32. Ability to determine how useful (clinically } \\
\text { applicable) the material is }\end{array}$ & $2.35(1.0)$ & $2.80(.89)$ & -.62 \\
$\begin{array}{l}\text { 33. Ability to apply information to individual } \\
\text { cases (ie integrate research evidence with } \\
\text { personal preferences, values, concerns, } \\
\text { expectations) }\end{array}$ & $2.35(.92)$ & $3.05(.94)$ & -.70 \\
* p p.05 & $2.40(.98)$ & $3.15(.93)$ & -.80 \\
\hline
\end{tabular}

In the terminology section students of the entry-level group never heard terms such most of the terms when compared to final-level students (Table 6). 
Table 5. Results of the Practice skills section of the EBP survey considering the students' level

\begin{tabular}{|c|c|c|c|c|}
\hline \multirow[t]{2}{*}{ Terminology domain } & \multicolumn{2}{|c|}{ Entry-level Group } & \multicolumn{2}{|c|}{ Final-level Group } \\
\hline & $\begin{array}{l}\text { Do not know } \\
\text { the term }\end{array}$ & $\begin{array}{l}\text { Understand } \\
\text { and could } \\
\text { explain to } \\
\text { others }\end{array}$ & $\begin{array}{l}\text { Do not know } \\
\text { the term }\end{array}$ & $\begin{array}{l}\text { Understand and } \\
\text { could explain to } \\
\text { others }\end{array}$ \\
\hline 6. Relative risk * & $20(50 \%)$ & 0 & $2(10 \%)$ & $2(10 \%)$ \\
\hline 7. Absolute risk * & $19(47.5 \%)$ & 0 & $2(10 \%)$ & $3(15 \%)$ \\
\hline 6. Systematic review* & $24(60 \%)$ & $1(2.5 \%)$ & $4(20 \%)$ & $4(20 \%)$ \\
\hline 9. Odds ratio & $34(85 \%)$ & $1(2.5 \%)$ & $12(60 \%)$ & 0 \\
\hline 10. Meta analysis* & $33(82.5 \%)$ & 0 & $1(5.0 \%)$ & $2(10 \%)$ \\
\hline $\begin{array}{l}\text { 11. Number needed to } \\
\text { treat* }\end{array}$ & $32(80 \%)$ & 0 & $5(25 \%)$ & $5(5 \%)$ \\
\hline 12. Confidence interval* & $33(82.5 \%)$ & $1(2.5 \%)$ & $2(10 \%)$ & $1(5 \%)$ \\
\hline 13. Publication bias* & $30(75 \%)$ & 0 & $4(20 \%)$ & $1(5 \%)$ \\
\hline 14. Forest plot & $36(90 \%)$ & 0 & $15(75 \%)$ & 0 \\
\hline 15. Intention to treat* & $17(42.5 \%)$ & $1(2.5 \%)$ & $5(25 \%)$ & $3(15 \%)$ \\
\hline 16. Statistical significance* & $16(40 \%)$ & $1(2.5 \%)$ & $1(5.0 \%)$ & $2(10 \%)$ \\
\hline $\begin{array}{l}\text { 17. Minimum clinically } \\
\text { worthwhile effect* }\end{array}$ & $18(45 \%)$ & 0 & $2(10 \%)$ & $3(15 \%)$ \\
\hline 18. Clinical importance* & $11(27.5 \%)$ & $1(2.5 \%)$ & $1(5.0 \%)$ & $3(15 \%)$ \\
\hline $\begin{array}{l}\text { 19. Randomised controlled } \\
\text { trial }(R C T)^{*}\end{array}$ & $24(60 \%)$ & $1(2.5 \%)$ & $1(5 \%)$ & $4(20 \%)$ \\
\hline 20. Dichotomous outcomes & $28(70 \%)$ & $1(2.5 \%)$ & $10(50 \%)$ & $2(10 \%)$ \\
\hline 21. Continuous outcomes* & $27(67.5 \%)$ & $1(2.5 \%)$ & $6(30 \%)$ & $2(10 \%)$ \\
\hline 22. Treatment effect size & $21(52.5 \%)$ & $1(2.5 \%)$ & $5(25 \%)$ & $1(5 \%)$ \\
\hline
\end{tabular}

Figure 1. The barriers reported by the students considering the students' level

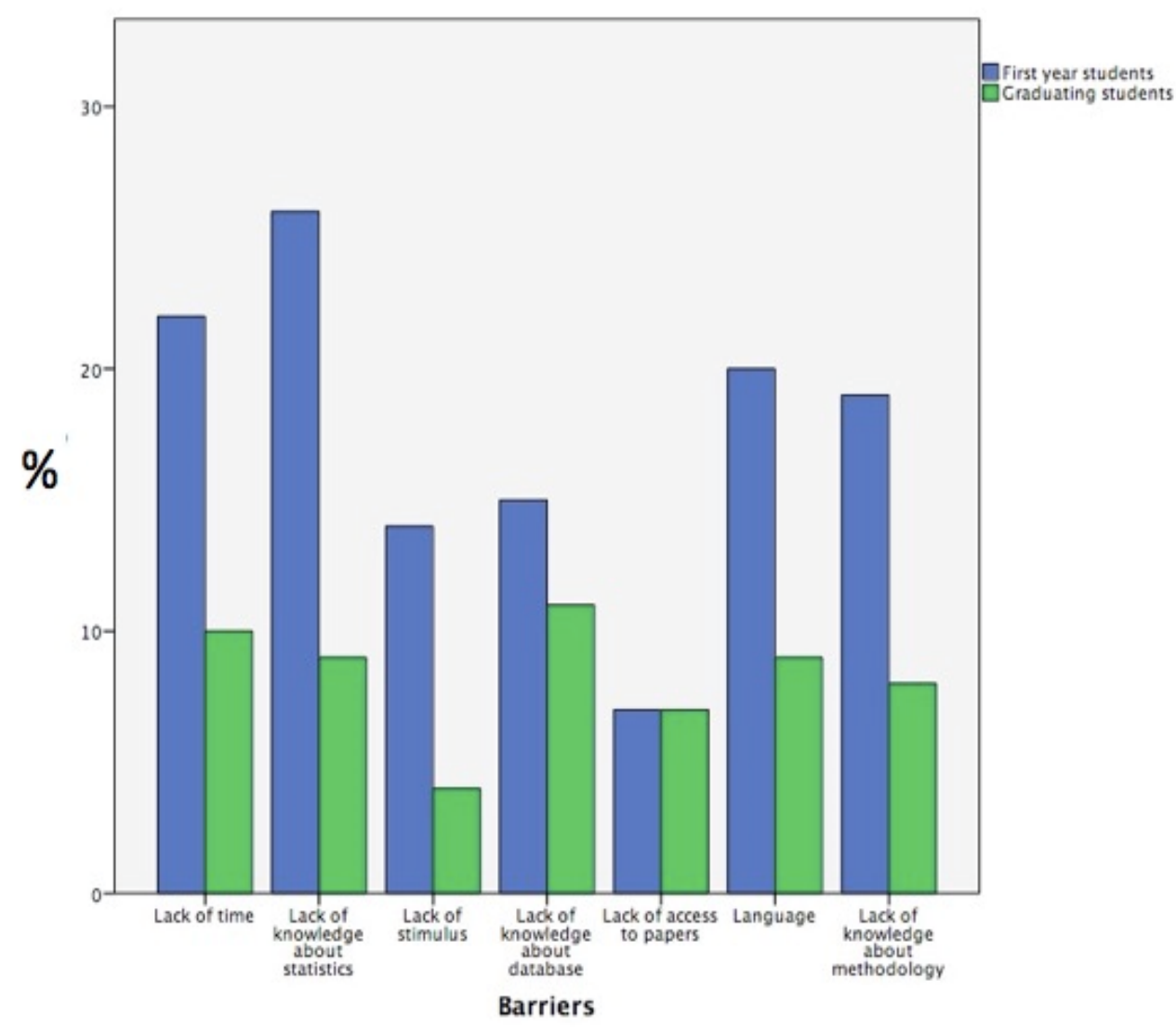

J. Évid-Based Healthc., Salvador, 2019 June; 1 (1):15-24 


\section{Discussion}

This study aimed to compare the level of knowledge between entry-level and final level physical therapy students about EBP relevance, knowledge, practice skills, and barriers. The difference between groups in all sections where not expressive. In the relevance section, the affirmatives aimed to investigate if students recognize the role of EBP in their graduation process and in their professional practice. Students of the final-level group presented a mean score slightly higher than the entry-level group. Studies in the literature identified positive attitudes towards EBP and research use in practice, with many students and professionals viewing EBP as a necessary part of their role which helped inform clinical decisionmaking ${ }^{21-23}$. A higher difference was observed in "I am aware of EBP in my profession" where students of the final-level showed to be more confident about the importance of EBP in clinical practice. This was also confirmed when students of the final-level group recognize that the affirmative "Workplace experience is the most reliable way to know what really works" as not being true. On the other hand, the entry-level group considered that clinical experience in the workplace is a reliable source of information.

The highest mean difference was observed in the terminology section where the final-level group showed mean higher scores in all components of this section. Students of the final-level group showed to understand terms such as "Absolute risk", "Systematic review", "Number needed to treat", "Publication bias", "Minimum clinically worthwhile effect" and "Clinical importance", "Randomized controlled trial (RCT)" more than students of the entry-level group. However, only "Number needed to treat" and "Publication bias" showed to be statistically significant. In this section, students were asked to rate their knowledge about a specific terminology (from "Do not know the term" to "Understand and could explain to others"). The majority of students of the entry-level do not know almost all terms. Surprisingly, more than a half of the students in the last group indicated that they do not know some terms like "Forest plot", "Odds ratio" and "Dichotomous outcomes".

The most intriguing finding of our study is the apparent respondents' confidence of their competence in various terms of the knowledge and in the practice skills section. Whereas some researchers have argued that self-reported high levels of competence and preparedness are correlated with good performance ${ }^{24}$, others have doubted whether self-assessment is a valid predictor of true competence ${ }^{25,26}$. Khan et al. ${ }^{27}$ found a weak association between participants' self evaluated knowledge and multiple choice test scores. Young et al. ${ }^{28}$ also found that physicians' selfratings of their understanding of terms used in EBM differed significantly from an objective, criterionbased assessment.

The most common barriers reported in this study were "lack of knowledge of statistics", "lack of time", "language" and "lack of knowledge about database". Several barriers to adopting evidence in clinical practice can be identified in the literature, including lack of time, limited access to literature, low confidence in the skills needed to identify and appraise research and poor support from colleagues and employers ${ }^{29-31}$. Strategies to improve EBP in physiotherapy should focus on ameliorating the barriers identified in previous studies and confirmed in the current study. Some solutions, such as providing easily understandable summaries and training students in searching and appraisal the evidence during graduation, may be relatively easy, whereas others, such as language proficiency and the lack of time may be more difficult. EBP training integrated clinically can be more interesting than stand-alone training and it could be integrated in some disciplines during the graduation course. To reduce the lack of time barrier, education should be tailored towards efficient use of online resources and targeting sources of pre-appraised literature. This could have a great effect on the time required for a student to perform evidence-based practice once the demands on healthcare professionals seem unlikely to be alleviated in the future. If such modifiable barriers are addressed, this may have a positive effect on physical therapy profession enhancing the provision of appropriate and effective care.

There are future challenges to be faced. First, we need to develop an effective EBP program to be implemented during the graduation process, and that remains in their future professional practice. Previous studies have demonstrated that, although measurable increases in basic knowledge and critical 
appraisal skills can be seen after participation in EBP program there is little evidence that knowledge and skills are taken outside the classroom and incorporated into actual patient care ${ }^{32,33}$. Second, it is essential to find the best moment, the contents of EBP that should be addressed and the ideal length of the course to implement EBP in Physical Therapy curriculum. In a recent prospective study that aimed to investigate EBP outcomes in entry-level physiotherapy students from baseline to completion of all EBP training (graduation), the authors found an increase in all domains with higher effect sizes in knowledge ( $E S=4.3 ; p \leq 0.001)$, terminology $(E S=3.13 ; p \leq 0.001)$ and relevance $(E S=2.29 ; p \leq$ $0.001)^{34}$. However, the length of the EBP curriculum delivered in this study (42 weeks over four years) can be challenging to implement in most Physical Therapy courses. Third, we should be aware of the teaching methodologies and learning process. It is possible that the delivery of EBP contents at a specific point in time during the Physical Therapy course is not ideal. On the other hand, the EBP contents should be distributed throughout the course using studentcentered learning ${ }^{35}$.

To the best of our knowledge, this study was the first to investigate the relevance, knowledge, practice skills and barriers among undergraduate Brazilian Physical Therapy students. Considering the small sample of this study and the fact that this study ran in only one University it is unknown to what extent our findings generalize to the entire population of physical therapy students. It may also be likely that our sample was biased because physical therapy students at Instituto Federal do Rio de Janeiro are used to search, read and appraise the literature in disciplines during the course. Although it was not collected during the study, it is possible that our sample presents homogeneous sociodemographic characteristics since most of the students at the Instituto Federal do Rio de Janeiro live in neighborhoods with mean human development index.

Indeed, it is possible that current physical therapy educational programs can leave graduates either with important gaps in training or with an exaggerated sense of their competencies. Such discrepancy may reflect a bigger problem of education-practice training mismatch. We recommend that EBP principles should be present in the Physical Therapy core Curriculum and addressed especially in clinical disciplines and during the practice in hospital and clinics.

\section{Conclusion}

In this study, we the difference in all sections about evidence based knowledge and attitudes where not expressive between the physical therapy students of the final-level compared to entry-level students. Regarding practice skills, students were not confident about their abilities in the EBP steps. A lack in understanding some terms of the EBP was observed especially in the entry-level.

\section{Author contributions}

All authors of this research paper have directly participated in the planning, execution, or analysis of this study. They have also read and approved the final version submitted.

\section{Competing interests}

No financial, legal or political competing interests with third parties (government, commercial, private foundation, etc.) were disclosed for any aspect of the submitted work (including but not limited to grants, data monitoring board, study design, manuscript preparation, statistical analysis, etc.).

\section{References}

1. Dubouloz CJ, Egan M, Vallerand J, von Zweck C. Occupational therapists' perceptions of evidence-based practice. Am J Occup Ther. 1999;53(5):445-53.

2. Sheldon TA, Guyatt GH, Haines A. Getting research findings into practice: When to act on the evidence. BMJ. 1998;317(7151):139-142.

3. Haines A, Haines A, Donald A. Getting research findings into practice. New York: John Wiley \& Sons; 2008.

4. Sackett DL, Rosenberg WMC, Gray JAM, Haynes RB, Richardson WS. Evidence based medicine: what it is and what it isn't. BMJ. 1996;312(7023):71-2.

5. McCluskey A. Occupational therapists report a low level of knowledge, skill and involvement in evidence-based practice. Aust Occup Ther J. 2003;50(1):3-12. doi: 10.1046/i.14401630.2003.00303.x 
6. Ilic D. Teaching evidence-based practice: perspectives from the undergraduate and post-graduate viewpoint. Ann Acad Med Singapore. 2009;38(6):559-5.

7. Aglen B. Pedagogical strategies to teach bachelor students evidence-based practice: a systematic review. Nurse Educ Today. 2016;36:255-63. doi: 10.1016/i.nedt.2015.08.025

8. Kyriakoulis K, Patelarou A, Laliotis A, Wan AC, Matalliotakis $M$, Tsiou $C$ et al. Educational strategies for teaching evidence-based practice to undergraduate health students: systematic review. J Educ Eval Health Prof. 2016;13:34. doi: 10.3352/jeehp.2016.13.34

9. Rosenberg W, Donald A. Evidence based medicine: an approach to clinical problem-solving. BMJ.

1995;310(6987):1122-6.

10. lles R, Davidson M. Evidence based practice: a survey of physiotherapists' current practice. Physiother Res Int. 2006; $11(2): 93-103$.

11. Bello Al. Utilizing research findings in physiotherapy: a call for gap bridging. J Niger Soc Physiother. $2011 ; 18$ (1 2):54-58.

12. Kumar S, Grimmer-Somers K, Hughes B. The ethics of evidence implementation in health care. Physiother Res Int. 2010;15(2):96-102. doi: $10.1002 /$ pri.479

13. Dannapfel P, Peolsson A, Nilsen P. What supports physiotherapists' use of research in clinical practice? A qualitative study in Sweden. Implement Sci. 2013;8(1):31. doi: $10.1186 / 1748-5908-8-31$

14. Stevenson K, Lewis M, Hay E. Do physiotherapists' attitudes towards evidence-based practice change as a result of an evidence-based educational programme? J Eval Clin Pract. 2004;10(2):207-17. doi: $10.1111 /$ i.13652753.2003.00479.x

15. Lizarondo L, Grimmer-Somers K, Kumar S. A systematic review of the individual determinants of research evidence use in allied health. J Multidiscip Healthc. 2011 ;4:261-272. doi: $10.2147 / J M D H . S 23144$

16. Young T, Rohwer A, Volmink J, Clarke M. What are the effects of teaching evidence-based health care (EBHC)? Overview of systematic reviews. PLoS One. 2014;9(1):e86706. doi: 10.1371/iournal.pone.0086706

17. Bernhardsson S, Larsson MEH, Eggertsen R, Olsen MF, Johansson K, Nilsen $\mathrm{P}$ et al. Evaluation of a tailored, multicomponent intervention for implementation of evidence-based clinical practice guidelines in primary care physical therapy: a non-randomized controlled trial. BMC Health Serv Res. 2014;14:105. doi: 10.1186/1472-6963-14-105
18. Mclnerney P, Suleman F. Exploring knowledge, attitudes, and barriers toward the use of evidence-based practice amongst academic health care practitioners in their teaching in a south African university: a pilot study. Worldviews Evid Based Nurs. 2010;7(2):90-7. doi: 10.1111/i.17416787.2009.00180.x

19. Perraton L, Machotka Z, Grimmer K, Gibbs C, Mahar C, Kennedy K. Embedding Evidence-based Practice Education into a Post-graduate Physiotherapy Program: Eight Years of pre-Post Course Evaluations. Physiother Res Int. 2017;22(2). doi: $10.1002 /$ pri.1659

20. Von Elm E, Altman DG, Egger M, Pocock SJ, Gøtzsche PC, Vandenbroucke JP et al. The Strengthening the Reporting of Observational Studies in Epidemiology (STROBE) Statement: guidelines for reporting observational studies. Int J Surg. 2014;12(12):1495-9. doi: 10.1016/i.ijsu.2014.07.013

21. Caldwell K, Coleman K, Copp G, Bell L, Ghazi F. Preparing for professional practice: how well does professional training equip health and social care practitioners to engage in evidence-based practice? Nurse Educ Today. 2007;27(6):518-28. doi: 10.1016/i. nedt.2006.08.014

22. Heiwe S, Kajermo KN, Tyni-Lenné R, Guidetti S, Samuelsson $M$, Andersson IL et al. Evidence-based practice: attitudes, knowledge and behaviour among allied health care professionals. Int J Qual Heal Care. 2011 ;23(2):198-209. doi: $10.1093 /$ intahc/mzq083

23. Jette DU, Bacon K, Batty C, Carlson M, Ferland A, Hemingway RD et al. Evidence-based practice: beliefs, attitudes, knowledge, and behaviors of physical therapists. Phys Ther. 2003;83(9):786-805. doi: 10.1093/pti/83.9.786

24. Schubert A, Tetzlaff JE, Tan M, Ryckman JV, Mascha E. Consistency, Inter-rater Reliability, and Validity of 441 Consecutive Mock Oral Examinations in Anesthesiology Implications for Use as a Tool for Assessment of Residents. Anesthesiol. 1999;91(1):288-98.

25. Gordon MJ. A review of the validity and accuracy of self-assessments in health professions training. Acad Med. $1991 ; 66(12): 762-9$.

26. Ward M, Gruppen L, Regehr G. Measuring selfassessment: current state of the art. Adv Heal Sci Educ Theory Pract. $2002 ; 7(1): 63-80$.

27. Khan KS, Awonuga AO, Dwarakanath LS, Taylor R. Assessments in evidence-based medicine workshops: loose connection between perception of knowledge and its objective assessment. Med Teach. $2001 ; 23(1): 92-4$. doi: $10.1080 / 01421590150214654$ 
28. Young JM, Glasziou P, Ward JE. General practitioners' self ratings of skills in evidence based medicine: validation study. Bmi. 2002;324(7343):950-1.

29. Sran MM, Murphy S. Postgraduate physiotherapy training: interest and perceived barriers to participation in a clinical master's degree programme. Physiother Can. 2009;61 (4):234-43. doi: 10.3138/physio.61.4.234

30. Wong SC, McEvoy MP, Wiles LK, Lewis LK. Magnitude of change in outcomes following entry-level evidence-based practice training: a systematic review. 2013;4:107-114. doi: $\underline{10.5116 / \mathrm{ijme} .51 \mathrm{a} 0 . \mathrm{fd} 25}$

31. Bozzolan M, Simoni G, Balboni $M$, Fiorini F, Bombardi $\mathrm{S}$, Bertin $\mathrm{N}$ et al. Undergraduate physiotherapy students' competencies, attitudes and perceptions after integrated educational pathways in evidence-based practice: a mixed methods study. Physiother Theory Pract. 2014;30(8):557-71. doi: $10.3109 / 09593985.2014 .910285$

32. Fraker LD, Orsay EM, Sloan EP, Bunney EB, Holden JA, Hart RG. A novel curriculum for teaching research methodology. J Emerg Med. 1996;1 4(4):503-8.

33. Serfass RL, Wonder AH. You're Teaching EvidenceBased Practice to BSN Students... But Are They Learning? Nurs Educ Perspect. 2018;39(3):172-4. doi: 10.1097/01. NEP.0000000000000283

34. McEvoy MP, Lewis LK, Luker J. Changes in physiotherapy students' knowledge and perceptions of EBP from first year to graduation: a mixed methods study. BMC Med Educ. 2018;18(1):109. doi: $10.1186 /$ s1 2909-018-1212-4

35. Reis FJJ, Monteiro MGM. Education in Physiotherapy: is it time to review the practice? Fisioter Pesqui.

2015;22(4):340-1. doi: 10.590/1809-

$\underline{2950 / 12729022042015}$ 